\title{
TRIASSIC PALEOMAGNETIC DATA FROM THE SUBBETIC AND THE MALAGUIDE COMPLEX OF THE BETIC CORDILLERAS (SOUTHEAST SPAIN)
}

\author{
GERARD H. MÄKEL ${ }^{1 *}$, HARM E. RONDEEL ' and JÖRGEN VANDENBERG ${ }^{2}$ \\ ' Geological Institute, University of Amsterdam, Nieuwe Prinsengracht 130, 1018 VZ Amsterdam (The \\ Netherlands) \\ 2 Paleomagnetic Laboratory, State University of Utrecht, Budapestlaan 17, 3584 CD Utrecht (The Nether- \\ lands)
}

(Received March 25, 1983; revised version accepted May 18, 1984)

\section{ABSTRACT}

Mäkel, G.H., Rondeel, H.E. and VandenBerg, J., 1984. Triassic palaeomagnetic data from the Subbetic and the Malaguide Complex of the Betic Cordilleras (southeast Spain). Tectonophysics, 101: 131-141.

The analysis of Triassic paleomagnetic directions from the Betic Cordilleras in southeast Spain indicates a considerable amount of relative displacement of the Subbetic of the External Zone of this orogen with respect to the Iberian block. The paleomagnetic pole positions of the Malaguide Complex of the Internal Zone of the orogen are closely related to those of the Subbetic. None of the poles coincide with European, African or Iberian poles of Permo-Triassic age.

\section{INTRODUCTION}

The geotectonic history of the lberian peninsula as a continental block has been documented by paleomagnetic data which indicate a counterclockwise rotation of $35^{\circ}$ relative to stable Europe. This rotation occurred between Barremian-Aptian and Maastrichtian time (VandenBerg, 1980). The relative position of the Internal Zone of the Betic Cordilleras-the alpine foldbelt of southern Spain-is, however, unknown for its entire history prior to the Miocene when it became attached to Iberia (Kampschuur and Rondeel, 1975).

The Internal Zone consists of a number of nappe complexes that underwent considerable deformation prior to the deposition of Middle Miocene sediments (Rondeel and Simon, 1974). The metamorphic complexes comprise Nevado-Filabride

\footnotetext{
* Present address: Koninklijke/Shell Exploratie \& Produktie Laboratorium, Volmerlaan 6, 2288 GD Rijswijk, The Netherlands.
} 
units, Alpujarride units and in addition in the eastern part, the Almagro and the Ballabona-Cucharón units. All of these complexes mainly contain sediments of Triassic and older age. The essentially non-metamorphic Malaguide Complex that tectonically overlies the Alpujarride Complex contains restricted amounts of younger rocks.

The Internal Zone is in tectonic contact with the External Zone of the Betic Cordilleras (Fig. 1). The External Zone can be subdivided in a (par)autochthonous Prebetic realm in the north and an allochtonous Subbetic in the south. In the Miocene the Subbetic has been thrust, in northern direction, over parts of the Prebetic. The External Zone contains deformed Triassic, Jurassic and Cretaceous sediments which are considered to be deposited on the southern continental margin of the Iberian block (Hermes, 1978; Garcia-Hernandez et al., 1980). The Triassic

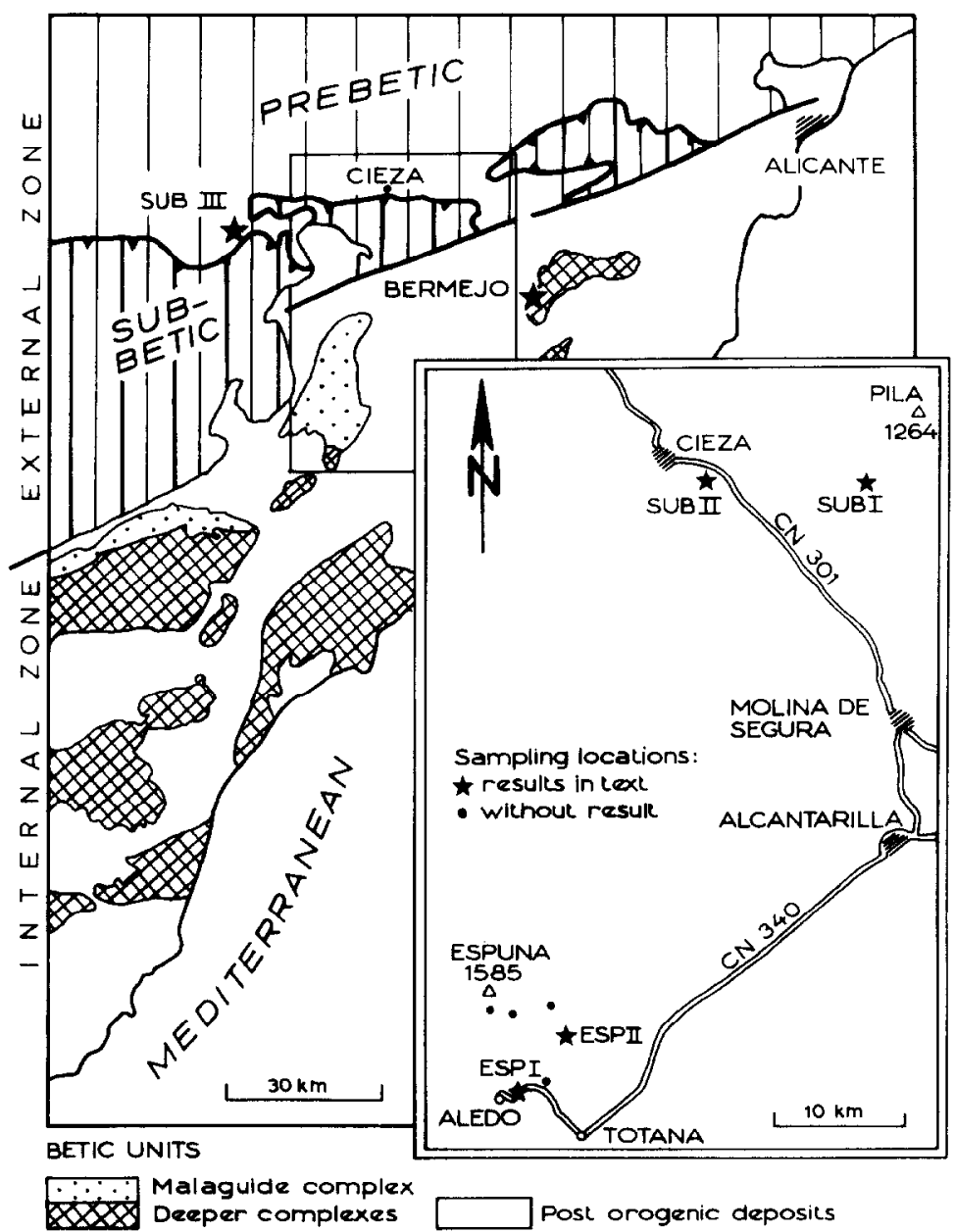

Fig. I. Geological sketch map of the eastern Betic Cordilleras showing the sample locations. 
sequence consists of red, detrital sediments and carbonates with abundant evaporites and served as an important level of detachment.

The Internal Zone has been considered to pertain to a Tethyan microblock (or plate) that became juxtaposed with the External Zone prior to the Middle Miocene (Kampschuur and Rondeel, 1975). Comparison of paleomagnetic data from the Internal Zone with Iberian data should thus give information about the paleogeographic position of this Zone relative to Iberia. Data from the External Zone should in principle relate almost directly to Iberian paleomagnetic directions.

The most suitable rock sequences for paleomagnetic sampling in the Internal Zone are those of the Malaguide Complex in view of their non-metamorphic character (Mäkel and Rondeel, 1979). The red sandstones of the Triassic seemed most suitable because of their composition and extension. In addition, Permo-Triassic paleomagnetic pole positions for Africa, Europe and the Iberian peninsula are rather well known (VandenBerg, 1980).

Samples have been collected in the Malaguide units of the Sierra de Espuña (Fig. 1), where Triassic rocks are extensively exposed (Mäkel and Rondeel, 1979). Furthermore, samples have been taken in the Sierra de Bermejo, where rocks ascribed to the Almagro unit appear to have been influenced only slightly by alpine deformation and metamorphism. Samples from the External Zone come from nearby locations in the Subbetic where Triassic red sandstones are amply exposed (Fig. 1).

\section{GEOLOGICAL SETTING OF THE SAMPLING LOCATIONS}

The Subbetic samples (SUB I and II) come from the basal part of the so-called Internal Subbetic, the higher of the Subbetic thrust masses, and (SUB III) from a so-called "Triassic" unit of imprecise tectonic position within the Subbetic (IGME, $1974 a)$. Location SUB I is situated at El Rellano $\left(38.13^{\circ} \mathrm{N}, 1.13^{\circ} \mathrm{W}\right)$, south of the Sierra de la Pila and location SUB II at the Rambla del Moro $\left(38.14^{\circ} \mathrm{N}, 1.23^{\circ} \mathrm{W}\right)$, southeast of Cieza (Fig. 1). At both locations the samples come from sharply bedded, clastic sequences of variegated crossbedded sandstones, siltstones and shales with thin intercalations of limestone and dolomite.

At location SUB I, the sequence dips $40^{\circ}-65^{\circ}$ to the south. The rocks are considered to pertain to the Keuper (IGME, 1974b). At location SUB II, the sequence dips between $45^{\circ}-80^{\circ}$, roughly to the east. Here the rocks, though of identical composition and stratigraphical position as at location SUB I, are assigned to the Buntsandstein (IGME, 1974b). Recent studies (Besems and Simon, 1982) indicate a Longobardian (Late Ladinian) age for the rocks at SUB II.

The samples (SUB III) from the "Triassic" unit have been taken in the area of Cehegin (Fig. 1). This unit occurs in front of the Subbetic thrust mass and tectonically overlies Cretaceous sediments. In a southern direction it disappears under the Jurassic and Cretaceous rocks of the Subbetic zone (IGME, 1974a). The samples come from two localities to the northeast of Cehegin. The first is roughly 4 
$\mathrm{km}$ east of Carrasquila $\left(38.13^{\circ} \mathrm{N}, 1.70^{\circ} \mathrm{W}\right)$, along the road that leads to the casa forestal on top of the hill $524 \mathrm{~m}$. The second $\left(38.14^{\circ} \mathrm{N}, 1.74^{\circ} \mathrm{W}\right)$ lies at the longitude of the Cabezos de la Fuente Capel, directly north of the road that leads from Carrasquila to the east. At both localities, the rocks are well-bedded, red coloured mudstones and crossbedded sandstones which dip $35^{\circ}-50^{\circ}$ in directions between south and southeast. These sediments have recently been dated as Julian (Middle Carnian) by Besems and Simon (1982).

Six locations, pertaining to different Malaguide tectonic units, were originally sampled in the Sierra de Espuña. Many samples did not provide reliable data, necessitating renewed sampling in 1979 and 1980. Only two locations produced sufficient reliable data and therefore only those locations will be discussed here. Location ESP I $\left(37.48^{\circ} \mathrm{N}, 1.34^{\circ} \mathrm{W}\right)$ is situated in a quarry alongside the road from Totana to Aledo, immediately southwest of the Monasterio de Santa Eulalia. The sequence here dips $20^{\circ}-60^{\circ}$ roughly to the northeast. Location ESP II $\left(37.50^{\circ} \mathrm{N}\right.$, $1.31^{\circ} \mathrm{W}$ ) lies approximately $1 \mathrm{~km}$ south of Casa de Campix, along the track crossing the Sierra. Here the sequence dips $20^{\circ}-50^{\circ}$ to the north. All samples are red and reddish crossbedded sandstones from the red conglomeratic member (Mäkel and Rondeel, 1979). This member forms the basal part of the Triassic sequences and is probably of Anisian age (Simon and Visscher, 1983).

The samples from the Sierra de Bermejo (BER; $38.04^{\circ} \mathrm{N}, 1.11^{\circ} \mathrm{W}$ ) have been taken directly south of the road from Santomera to Espinardo. They come from a $40^{\circ}-65^{\circ}$ ENE dipping, well-bedded sequence of mainly reddish quartzites belonging to the Bermejo unit which tectonically underlies the Orihuela unit. These quartzites occur in the higher part of the Mina formation and they can therefore be dated as Early to Middle Triassic, probably Ladinian (IGME, 1974c).

\section{SAMPLE PREPARATION AND MEASUREMENTS}

In the Paleomagnetic Laboratory of the State University of Utrecht (Fort Hoofddijk) core specimens ( $2.2 \mathrm{~cm}$ height, $2.5 \mathrm{~cm}$ diameter) were drilled from hand samples. Measurement of the natural remanent magnetization was carried out on the JR-3 spinner magnetometer and on the ScT cryogenic magnetometer. The specimens were subjected to stepwise AF-demagnetization to $300 \mathrm{mT}$ and to thermal demagnetization up to $700^{\circ} \mathrm{C}$ for separation of the various magnetization components. Thermal demagnetization proved to be the most adequate technique and therefore all specimens were thermally demagnetized in at least eight steps.

The magnetization components could be separated and their directions determined with the help of orthogonal projection diagrams. These-diagrams show the sequential changes of the magnetization vector upon demagnetization. Representative examples are shown in Fig. 2. A remanent magnetization component with low blocking temperatures was removed during heating from $100^{\circ}$ to $400^{\circ} \mathrm{C}$ and is most likely of secondary origin. A component with high blocking temperatures, is re- 
RN 412

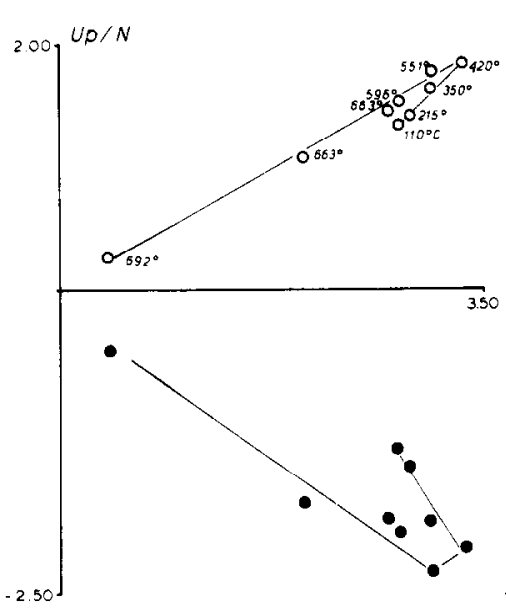

RN 511

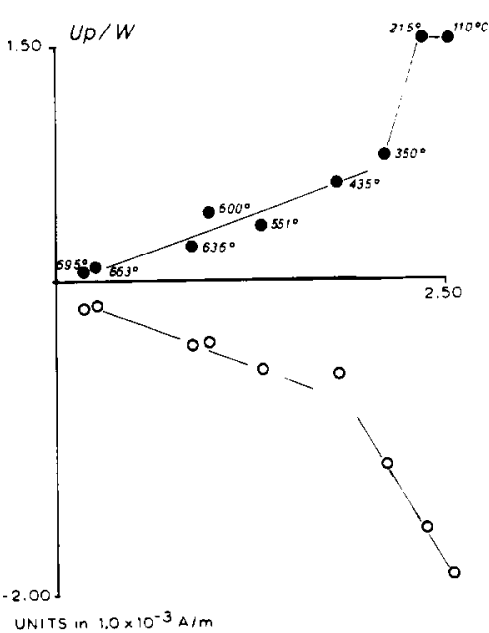

RN 761

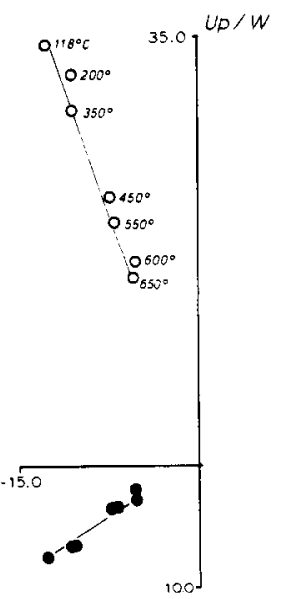

Fig. 2. Orthogonal projection figures of the remanent magnetization vector path during demagnetization. Solid dots denote projections on the horizontal plane and open circles on the vertical $\mathrm{E}-\mathrm{W}$ or $\mathrm{N}-\mathrm{S}$ planes. Numbers are values of furnace temperatures during thermal cleaning in ${ }^{\circ} \mathrm{C}$. Specimen $\mathrm{Rn} 41 / 2$ comes from location SUB I; Rn 51/1 from SUB II and Rn 76/1 from ESP I.

moved during subsequent heating from $400^{\circ}$ to $700^{\circ} \mathrm{C}$ and is taken to represent the characteristic magnetization component, residing mainly in hematite grains. The clastic nature of the continental redbeds justifies the assumption that the hematite minerals are of primary origin.

\section{TABLE I}

Summary of characteristic paleomagnetic results from Triassic rocks of the eastern Betic Cordilleras

\begin{tabular}{|c|c|c|c|c|c|c|c|c|c|c|c|c|}
\hline \multirow[t]{2}{*}{ LOCATION } & \multirow[t]{2}{*}{$N$} & \multicolumn{7}{|c|}{ MAGNETIZATION DIRECTION } & \multicolumn{4}{|c|}{ PALEOMAGNETIC POLE } \\
\hline & & $\mathrm{Decl} / \mathrm{Incl}$ & $\bar{a}$ & 95 & $x$ & $k^{*}$ & $k / x^{*}$ & $F$ & $\overline{\mathrm{Lat} / \mathrm{I}}$ & ong & $d p$ & $\mathrm{dm}$ \\
\hline ESP I & $16(9)$ & $299 /-07$ & .96 & 8.1 & 23.1 & 18.0 & 1.23 & 1.84 & $20 \mathrm{~N}$ & $113 !$ & 4.1 & 8.2 \\
\hline ESP 11 & $16(1)$ & $336 / 01$ & .89 & 14.0 & 9.1 & 9.9 & 0.92 & 1.88 & $47 N$ & $146 \mathrm{~W}$ & 7.0 & 14.1 \\
\hline MALAGUIDE. COMPLEX & 31 & $316 /-74$ & .87 & 10.0 & 7.8 & 7.6 & 1.02 & 1.53 & $33 \mathrm{~N}$ & $126 \mathrm{H}$ & 5.1 & 10.2 \\
\hline BER & $19(6)$ & $270 / 22$ & 51 & 43.3 & 1.8 & 2.6 & 0.69 & 1.98 & & & & \\
\hline SUB I & $19(5)$ & $310 /-08$ & .88 & 15.6 & 8.1 & 7.5 & 1.08 & 1.93 & $27 N$ & $122 W$ & 7.9 & 15.7 \\
\hline SUB II & $20(4)$ & $324 / 05$ & .85 & 15.3 & 6.5 & 3.8 & 1.71 & 1.84 & $41 N$ & $130 w$ & 8.2 & 16.3 \\
\hline SUB III & $14(1)$ & $299 /-05$ & .92 & 12.7 & 12.6 & 10.2 & 1.24 & 1.98 & $21 \mathrm{~N}$ & $113 ! !$ & 6.4 & 12.8 \\
\hline SUBBET IC & 43 & $311 / 02$ & .86 & 8.9 & 7.2 & 4.2 & 1.71 & 1.44 & $32 \mathrm{~N}$ & $119 W$ & 4.5 & 8.9 \\
\hline
\end{tabular}

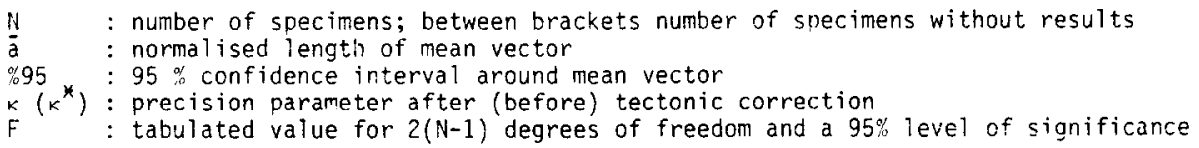




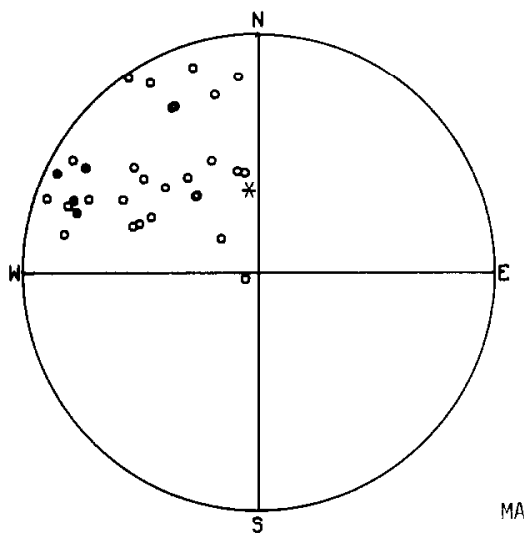

BEFORE TECTONIC CORRECTION

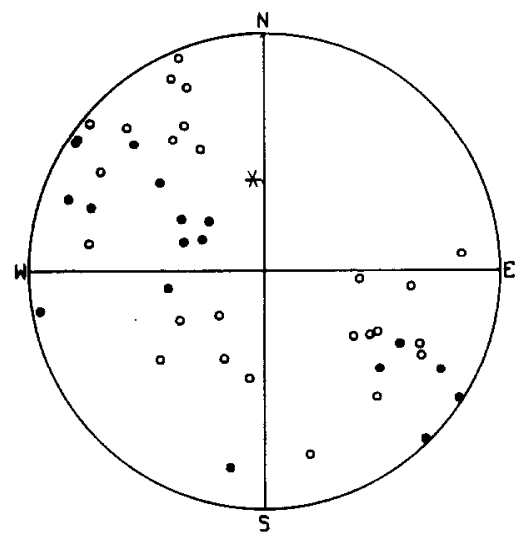

BEFORE TECTONIC CORRECTION

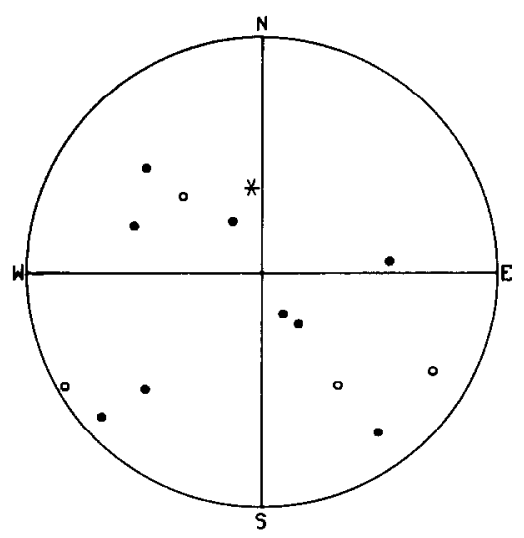

BEFORE TECTONIC CORRECTION

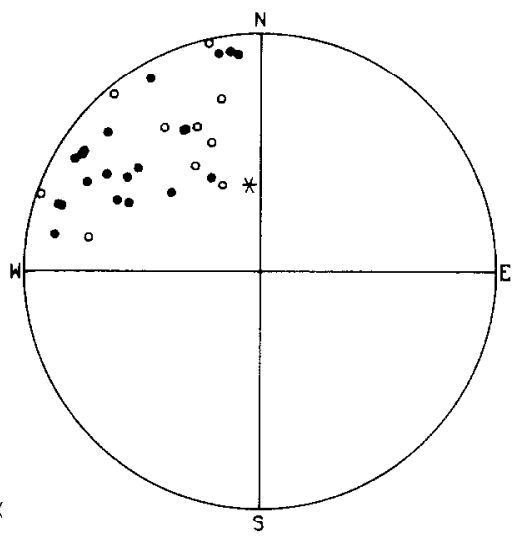

AFTER TECTONIC, CORRECTION

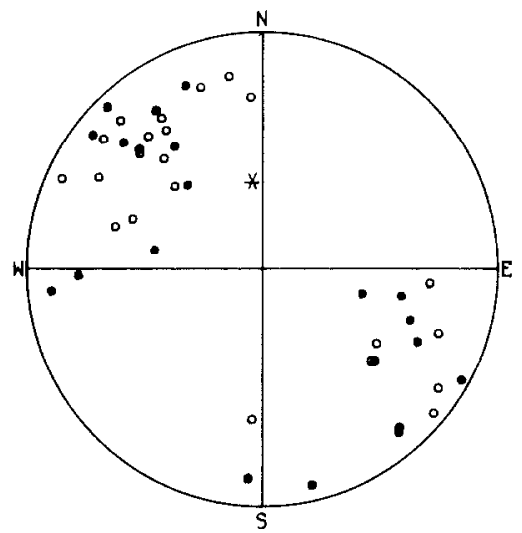

AFTER TECTONIC CORRECTION

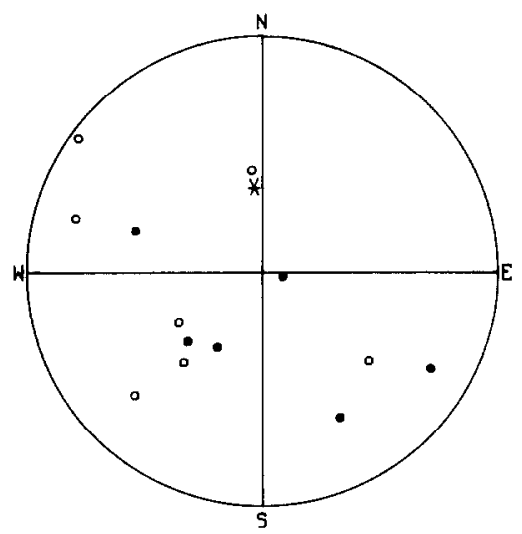

AFTER TECTONIC CORRECTION

Fig. 3. Equal area projections of the paleomagnetic directions. Full circles denote negative and open circles positive inclinations. The asterisk denotes the present magnetic field at Madrid. 
The secondary magnetization components have either spurious directions or are antiparallel to the characteristic magnetization component which has typically low inclination values. Only 17 out of a total of 110 specimens showed a magnetic behaviour which did not allow a reliable determination of the magnetization direction. These results were omitted from further consideration.

Summary statistics for the directions before and after correction for bedding-plane tilt were calculated for each sampling location and for the Subbetic and the Malaguide locations combined. These statistics are based on the Fisher distribution for directions distributed on a sphere (Fisher, 1953) and they are listed in Table I.

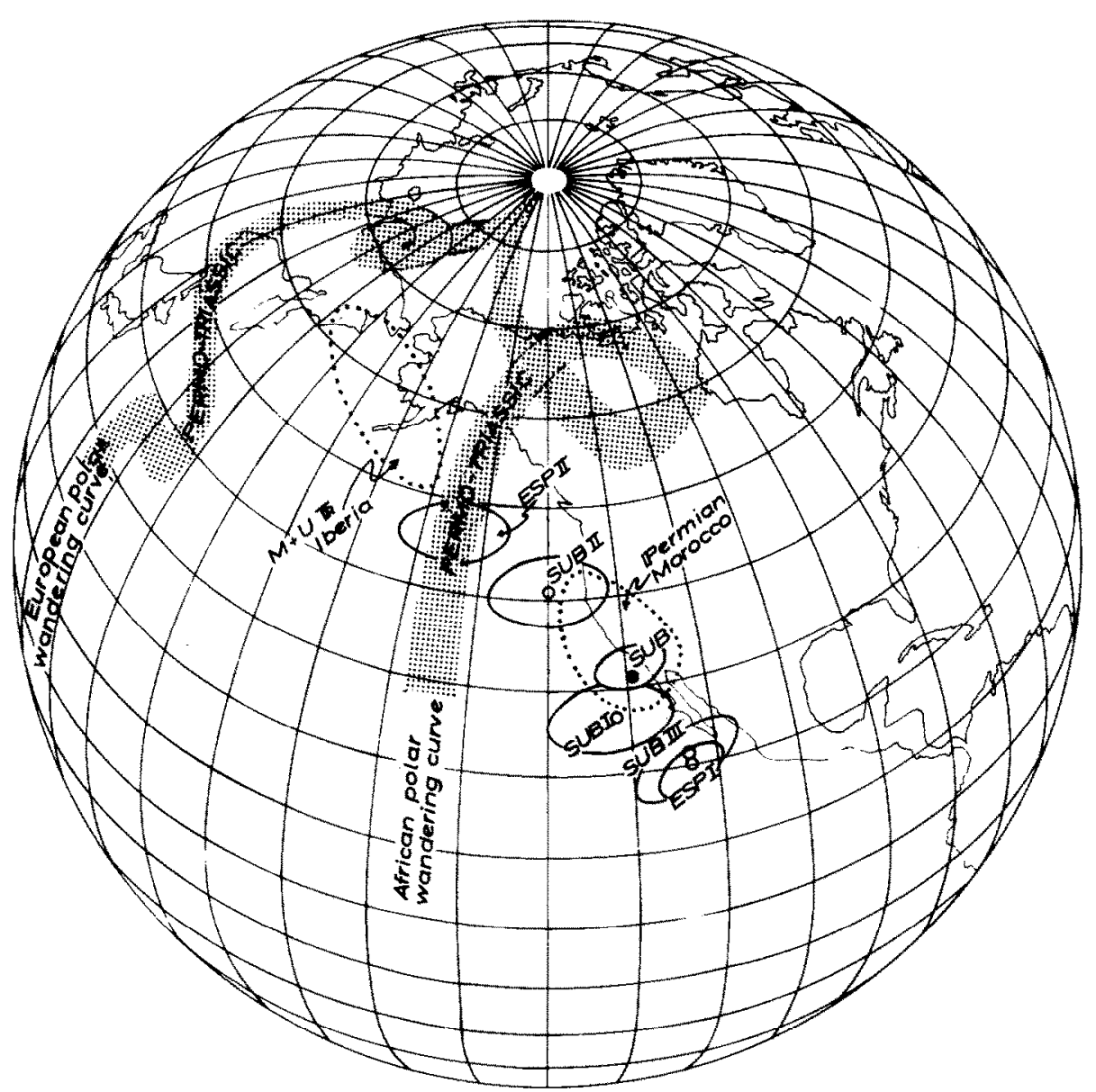

Fig. 4. Equal area projection of the Triassic paleomagnetic poles for the Subbetic and Malaguide Complex with respect to apparent polar wandering curves for Europe and Africa. (Permo-)Triassic pole positions for Iberia and Morocco are indicated with dotted lines. Polar wandering curves and data for Iberia and Morocco after VandenBerg and Zijderveld (1983). 
The results of an $F$-test (McElhinny, 1964) on the ratio of the precision parameters $\left(\kappa / \kappa^{*}\right)$ after and before tectonic correction are also listed.

\section{ANALYSIS OF PALEOMAGNETIC RESULTS}

The directional data of the characteristic magnetization components are shown in the stereographic projections of Fig. 3. The tectonic correction improved the clustering of most data except for ESP II and BER which is explained by the fact that the samples come from sequences with rather uniform dip in a single direction. Therefore only minor improvement in clustering of the data can be expected. Clustering improved slightly for the combined data of the Malaguide locations (ESP I and ESP II). For the combined results of the Subbetic locations (SUB I, II \& III), the $F$-test on the ratio of the concentration parameters is significant at a $95 \%$ level of significance (i.e. $\kappa / \kappa^{*}>F_{2(N-1)}$ ).

The Subbetic data comprises normal and reversed paleomagnetic directions with typical low inclination values (Fig. 3). They depart significantly from the present local field direction. Together with the high blocking temperature (hematite) of the characteristic magnetization component, this justifies a comparison of the results with published data of Permo-Triassic age from Iberia and Africa.

Despite the fact that the three Subbetic locations come from different tectonic units, the paleopole positions are broadly similar. Furthermore, the foldtest for the combined data shows a positive result. The results have therefore been combined and a mean paleopole has been calculated.

Differences between the results of the locations in the Internal Zone are more pronounced. Especially the results from location BER show a large scatter which considerably increased upon tectonic correction (Fig. 3; Table I). Deformation and metamorphism are held responsible for this effect. The results of this location are omitted from further consideration. With respect to the Malaguide data the differences between the results, which are reflected in the negative result of the combined foldtest, do not justify the calculation of a mean paleopole position.

The paleopoles of the individual locations, as well as the Subbetic mean paleopole, have been plotted in Fig. 4. Comparison with the apparent polar wandering curves for Europe and Africa and with (Middle- and Upper-) Triassic poles from Iberia (VandenBerg and Zijderveld, 1983), shows that the poles from the Malaguide Complex and Subbetic of the Betic Cordilleras do not coincide with Iberian Triassic poles.

\section{DISCUSSION}

In the literature it has been generally accepted that the Subbetic sediments have been deposited on the southern continental margin of the Iberian block (Hermes, 1978; Garcia-Hernandez et al., 1980). This opinion has been primarily based on a 
lithological comparison of post-Triassic sequences of the Subbetic with sequences of the (par)autochtonous Prebetic. Thus the Subbetic is considered to belong to the Iberian block. This would imply that the Iberian rotation also affected the External Zone and ought to be recorded by the paleomagnetic directions in the pre-Cretaceous Subbetic rocks. Therefore one would expect the Triassic paleopole of the Subbetic to be consistent with those from Iberia. However, this is not the case, as shown in Fig. 4.

The Internal Zone of the Betic Cordilleras comprises a number of metamorphic nappe complexes overlain by the essentially non-metamorphic Malaguide Complex (Mäkel and Rondeel, 1979). The paleogeographic arrangement of these complexes and especially the paleogeographic position of the Malaguide Complex has been a matter of considerable debate (Kampschuur and Rondeel, 1975; Egeler and Simon, 1969; Simon et al., 1976; Torres-Roldan, 1979; Durand Delga, 1980). Most authors agree with a southern (African s.1.) derivation of the Alpujarride Complex. For the Malaguide Complex either a northern (Iberian s.1.) or a southern (African s.1.) position, relative to the Alpujarride Complex, is generally considered. The analysis of paleocurrent directions, measured in Triassic fluvial sequences of different tectonic units in the Sierra de Espuña and more westerly areas, excludes large scale rotations of units within the Malaguide Complex (Mäkel, 1982). In the Espuña area, the emplacement of the Malaguide units involved two phases of thrusting which, by implication of the paleocurrent analysis, mainly involved translation (Mäkel, 1981). The paleomagnetic data from the Malaguide Complex alone cannot solve the problem of its paleogeographic position relative to the other complexes in the Internal Zone. For that aim paleomagnetic data from the Alpujarride complex are needed. In view of the complex metamorphic history of the Alpujarride Complex, it seems unlikely that such data will become available.

The positions of the Malaguide paleopoles are relative close to the mean Subbetic pole. The amount of displacement of Subbetic sequences relative to the (par)autochtonous Prebetic and hence to the Iberian block is generally considered to be small, e.g., in the eastern Betic Cordilleras it has been estimated in the order of $20 \mathrm{~km}$ (Rondeel and Simon, 1974). However, comparison of Iberian paleopole positions with those from the Betic Cordilleras indicates a much larger amount of displacement for individual units within the Subbetic and the Malaguide Complex. This amount of displacement, implied by the paleopole positions, does not figure in existing paleogeographic reconstructions of the Betic Cordilleras.

Inspection of Fig. 4 shows that the Subbetic and Malaguide Triassic poles coincide with Permian poles from locations in Morocco, north of the South Atlas fault (Morel et al., 1981). These Moroccan poles pose a problem in the reconstruction of the Western Mediterranean area (VandenBerg and Zijderveld, 1983). Their anomalous position relative to the Late Paleozoic part of the African polar wandering curve (Fig. 4) leads to two different assumptions as to their cause: either the Late Paleozoic part of the African curve is not known in sufficient detail or the Moroccan 
area moved relative to Africa. The fact that the poles from the Betic Cordilleras do not coincide with the Permo-Triassic part of the African curve but coincide with the Permian poles from Morocco, encourages speculations on the relation between the Betic Cordilleras and Morocco. The coincidence of the poles supports the hypothesis of a Tethyan microblock, comprising the Betic Cordilleras and Morocco. It is possibly comparable to the Alboran microplate of Andrieux et al. $(1971,1973)$ in which the Malaguide and Subbetic units should participate. Obviously more data are needed to prove this hypothesis.

\section{CONCLUSIONS}

Analysis of Triassic paleomagnetic data from the External Zone of the Betic Cordilleras does not confirm a direct relation between the Subbetic and the Iberian block. The Triassic paleopoles for the Subbetic sequences agree at large with the Malaguide poles, as part of the Internal Zone.

The paleopoles from the Betic Cordilleras do not coincide with European. African or Iberian Triassic poles, but they seem to agree with Permian poles from Morocco. The Betic pole positions indicate a considerable amount of movement, relative to the Iberian block, of the Subbetic and Malaguide sequences.

\section{ACKNOWLEDGEMENTS}

Prof. Dr. J.D.A. Zijderveld, Dr. O.J. Simon and Dr. M.A. Naylor contributed valuable comments which improved the manuscript.

\section{REFERENCES}

Andrieux, J., Fontboté, J.M. and Mattauer, M., 1971. Sur un modèle explicative de larc de Gibraltar. Earth Planet. Sci. Lett., 12: 191-198.

Andrieux, J. and Mattauer, M., 1973. Precision sur un modele explicative de l'arc de Gibraltar. Bull. Soc. Géol. Fr., (7), 15: 115-118.

Besems, R.E. and Simon, O,J, 1982. Aspects of Middle and Late Triassic palynology. 5. On the Triassic of the Subbetic Zone in the province of Murcia (Betic Cordilleras, southeastern Spain). Proc. K. Ned. Akad. Wet., B85: $29-52$.

Durand Delga, M., 1980. La Méditerranée occidentale: étapes de sa genèse et problèmes structuraux liés à celle-ci. Mem. Soc. Géol. Fr. 10: 203-224.

Egeler, C.G. and Simon, O.J., 1969. Sur le tectonique de la Zone Bétique (Cordillères Bétiques, Espagne). Proc. K. Ned. Akad. Wet., I-25(3): 90 pp.

Fisher, R.A., 1953. Dispersion on a sphere. Proc. R. Soc. London, Ser. A, 217: 295-305.

Garcia-Hernandez, M., Lopez Garrido, A.C., Rivas, P., Saenz de Galdeano, C. and Vera, J.A., 1980. Mesornic paleogengraphic evolution of the Fxternal 7one of the Retic Cordilleras. Genl. Mijnhouw 59: $155-168$.

Hermes, J.1., 1978. The stratigraphy of the Subbetic and southern Prebetic of the Velez Rubio-Caravaca area and its bearing on transcurrent faulting in the Betic Cordilleras of southern Spain. Proc. K. Ned. Akad. Wet., B81: 1-54. 
IGME, 1974a. Mapa geologico de España escala 1:50.000; Explication de la hoja 25-36(911) Cehegin. Inst. Geol. Min. España.

IGME, 1974b. Mapa geologico de España escala 1:50.000; Explication de la hoja 26-35(891) Cieza. Inst. Geol. Min. España.

IGME, 1974c. Mapa geologico de España escala 1:50.000; Explication de la hoja 27-36(913) Orihuela. Inst. Geol. Min. España.

Kampschuur, W. and Rondeel, H.E., 1975. The origin of the Betic Orogen, southern Spain. Tectonophysics, 27: 39-56.

Mäkel, G.H., 1981. Differences in tectonic evolution of superposed Malaguide and Alpujarride tectonic units in the Espuña area (Betic Cordilleras, Spain). Geol. Mijnbouw, 60: 203-208.

Mäkel, G.H., 1982. Statistical analysis of paleocurrent directions in the Malaguide Complex in the zone from Chirivel to the Sierra de Espuña (Betic Cordilleras, Spain). Proc. K. Ned. Akad. Wet., B85: 241-248.

Mäkel, G.H. and Rondeel, H.E., 1979. Differences in stratigraphy and metamorphism between superposed Malaguide and Alpujarride units in the Espuña area (Betic Cordilleras, SE Spain). Estud. Geol., 35: $109-117$.

McElhinny, M.W., 1964. Statistical significance of the fold test in paleomagnetism. Geophys. J.R. Astron. Soc., 8: 338-340.

Morel, P., Irving, E., Daly, L. and Moussine-Pouchkine, A., 1981. Paleomagnetic results from Permian rocks of the northern Saharan craton and motions of the Moroccan Meseta and Pangea. Earth Planet. Sci. Lett., 55: 65-74.

Rondeel, H.E. and Simon, O.J., 1974. Betic Cordilleras. In: A.M. Spencer (Editor), Mesozoic-Cenozoic belts. Data for orogenic studies. Geol. Soc. London, Spec. Publ., 4: 23-35.

Simon, O.J. and Visscher, H., 1983. On the Permian of the Betic Cordilleras (southern Spain). Proc. Congr. Carboniferous Iberian Peninsula, Madrid.

Simon, O.J., Westerhof, A. and Rondeel, H.E., 1976. A propos d'une nouvelle paléogéographie de la Zone Bétique (Espagne Méridional): Implications géodynamiques. Bull. Soc. Géol. Fr., 3(18): 603-605.

Torres-Roldan, R.L., 1979. The tectonic subdivision of the Betic Zone (Betic Cordilleras, southern Spain): its significance and one possible geotectonic scenario for the westernmost alpine belt. Am. J. Sci. 259: 19-51.

VandenBerg, J., 1980. New Paleomagnetic data from the Iberian peninsula. Geol. Mijnbouw, 59: 49-60. VandenBerg, J. and Zijderveld, J.D.A., 1983. Paleomagnetism in the Mediterranean area. In: Alpine Mediterranean Geodynamics. Am. Geophys. Union, Gedyn. Ser., 7: 83-112. 